\title{
HAJI FUNDS FOR INFRASTRUCTURE INVESTMENT
}

\section{DANA HAJI UNTUK INVESTASI INFRASTRUKTUR}

\author{
Muh. Fudhail Rahman \\ UIN Syarif Hidayatullah Jakarta \\ Jl. Ir H. Juanda No.95, Cemp. Putih, Kota Tangerang Selatan \\ Email: fudhail.rahman@uinjkt.ac.id \\ Shubhan Shodiq \\ UIN Syarif Hidayatullah Jakarta \\ Jl. Ir H. Juanda No.95, Cemp. Putih, Kota Tangerang Selatan \\ Email: subhanshodiq@gmail.com \\ Aida Humaira \\ Fakultas Dirasat Islamiyah UIN Syarif Hidayatullah Jakarta \\ Jl. Ir H. Juanda No.95, Cemp. Putih, Kota Tangerang Selatan \\ Email: aida.humaira@uinjkt.ac.id
}

Naskah diterima tanggal 16 Maret 2020, Naskah direvisi tanggal 9 April 2020, Naskah disetujui tanggal 9 Juni 2020

\begin{abstract}
As an implementation of the conditions for istita'ah, for person who want to register pilgrimage, the government requires paying amount of money called Biaya Penyelenggaraan Ibadah Haji (BPIH). The accumulated funds have reached untill trillions of rupiah, this accumulation has potential to be developed. Currently, there is debate about the permissibility of using BPIH outside the direct interests of pilgrims such as government infrastructure investment. This research uses normative juridical research. This study also uses a statutory approach and a comparative approach. The results of this study indicate the pilgrimage fund can be invested. However, in terms of the ability to use the pilgrimage funds for investment in government infrastructure, there must be permitted by people who want to go on pilgrimage, or can be used in infrastructure that is directly related to the pilgrimage.
\end{abstract}

Keywords: haj funds, infrastructure investment, islamic law, state law

\begin{abstract}
Abstrak
Sebagai implementasi dari syarat istita'ah, bagi calon Jemaah haji yang hendak mendaftar haji, pemerintah mewajibkan membayar sejumlah uang yang disebut dengan setoran awal Biaya Penyelenggaraan Ibadah Haji (BPIH). Akumulasi dana yang terkumpul mencapai triliunan rupiah, hal ini sangat potensial untuk dikembangkan, dan jika didiamkan begitu saja akan berpotensi terjadi inflasi. Saat ini terdapat perdebatan tentang hukum kebolehan menggunakan BPIH diluar kepentingan langsung jemaah haji seperti investasi infrastruktur pemerintah. Penelitian ini menggunakan jenis penelitian yuridis normatif (penelitian hukum normatif). Penelitian ini juga menggunakan pendekatan undang-undang (statutory approach), dan pendekatan perbandingan (comparative approach). Hasil penelitian ini menunjukan dana haji dapat diinvestasikan, karena jika dibiarkan begitu saja akan tidak produktif dan berpotensi inflasi. Akan tetapi, dalam hal kebolehan penggunaan dana haji untuk investasi infrastruktur pemerintah penulis berpendapat harus adanya kerelaan dari calon Jemaah haji atau digunakan dibidang infrastruktur yang berkaitan langsung dengan Jemaah haji.
\end{abstract}

Kata Kunci: dana haji, investasi infrastruktur dan hukum 


\section{PENDAHULUAN}

$\mathrm{T}$ The fifth pillar of Islam is to perform the pilgrimage to the holy land of Mecca. The implementation of the fifth pillar of Islam is not mandatory for everyone. Only to those who are classified as a capable person must be fulfil this obligation. Although what is considered capable of performing he Hajj includes several elements, but specifically it refers to the ability from the aspect of financial capability.

In Indonesia, the implementation of the condition of being able to (istita'ah), the government requires payment of a certain amount of money for prospective pilgrims to get the haj quota. The increasing number of pilgrims waiting (waiting list) resulted in fund accumulation of pilgrimage funds. Based on mandate in the constitution no.34 of 2014 concerning Hajj Financial Management, Hajj financial management is handled by a special institution called the Hajj Financial Management Agency (abbreviated by BPKH). BPKH charge of managing the Hajj Finance which includes the reception, development, expenditure and financial accountability.

BPKH data as cited by the author from the Kompas.com newspaper shows that the pilgrimage funds collected as of 30 June 2017 reached $\mathrm{Rp} 99.34$ trillion. This amount consists of a benefit value of IDR 96.29 trillion and a community endowment fund of IDR 3.05 trillion. From this breakdown, the pilgrimage fund invested benefits in the form of a 50 percent Hajj Cost Subsidy (subsidized cost). The total cost of the pilgrimage that should have been paid was Rp. 68 million per prospective congregation. With these subsidies, it was reduced by half to $\mathrm{Rp} 34$ million. (Anggito Abimanyu, Kompas, 10 October 2017)

Along with the large amount of pilgrimage funds collected, Indonesia as a developing country requires enormous costs to develop infrastructure in various regions. As the author quotes through the okezone.com newspaper, total infrastructure financing needs reached $\mathrm{Rp} 4,769$ trillion over five years (2015-2019). While the source of government investment from the state budget and regional budget is only around $41.3 \%$ or as much as Rp. 1,969 trillion. The amount of funds needed and a limited budget encourage the government to involve other parties to participate in investing in infrastructure development. President Joko Widodo (Jokowi) after inaugurating the Supervisory Board and members of the Hajj Financial Management Board (BPKH) at the State Palace, Jakarta, Wednesday, July 26, 2017, proposed that the pilgrimage funds be invested in infrastructure financing.

The Discourse to invest Hajj funds into infrastructure has caused controversy. Chairman of the Indonesian Scholars Council (MUI) Ma'ruf Amin as quoted by tribbunnews.com did not question the plan to use the pilgrimage fund for infrastructure development. Ma'ruf explained, Hajj funds may indeed be invested. Ma'ruf said, there were already funds of around Rp 35 trillion for Retail State Sharia Securities or State Sharia Securities (SBSN).

The opposite opinion was expressed by the Deputy Chairman of the Indonesian House of Representatives (DPR RI), as quoted by the beritagar.id newspaper Fahri Hamzah criticized the reasons for investing Hajj funds for infrastructure development. Fahri said, there are still many pilgrimage issues that need to be prioritized to be solved. Fahri rate, the plan has the potential to violate Law Number 34 of 2014 concerning Hajj Financial Management. According to him, Hajj funds should be used to improve Hajj services that are still problematic.

Basically, in Islamic law, a person is also prohibited from making use of the assets of others, but must be with his permission. The Jurisprudence in Fiqh states:

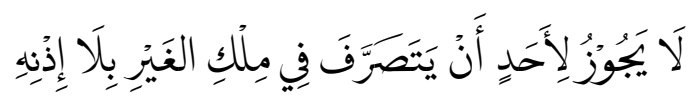

"A person must not use people's property without his permission" (Abd. Aziz, 2005)

Based on the description above, this research will discuss the use of hajj funds for infrastruct ure investment in the perspective of Islamic law and positive law with the specification of the problem formulation as 
follows: a. How is the use of Hajj funds for infrastructure investment according to Islamic law based on the results of the Ijtima Ulama of the Indonesian Ulama Council (MUI) and the bahtsul masail of the Nahdlatul Ulama Ulama (NU)? b. How is the use of Hajj funds for infrastructure investment according to positive law? c. How does the legal use of Hajj funds for infrastructure investment compare between Islamic law and positive law?

This research is expected to add insight into the legal basis for managing the costs of organizing the hajj pilgrimage (BPIH) as well as the law of investing in infrastructure according to Islamic law and positive law. In addition, this research can be considered in making decisions related to the management of the pilgrimage funds.

\section{RESEARCH METHODS}

This type of research is normative legal research. Normative legal research is legal research that places law as a norm building system. The norm system in question is about the principles, norms, rules of the laws and regulations, court rulings, agreements and doctrines (teachings) (Mukti Fajar \& Yulianto, 2015: 35). Normative legal research is also a process to find a rule of law, legal principles, and legal doctrine to address the legal problems faced (Peter Mahmud Marzuk, 2005: 35).

The approachment method used in this study is the statutory approach (Statute Aprroach) and the comparative approach (Comparative Approach). The statute approach (Statute Approach) is carried out by examining the laws and regulations relating to the legal issues being addressed (Peter Mahmud Marzuk, 2005: 133). While the comparative approach (Comparative Approach) taken in this thesis by comparing between positive law and Islamic law.

In the process of collecting data, the author uses the method of library research. This method is carried out to achieve a comprehensive understanding of the concepts to be studied. Data obtained through library research comes from legislation, books, official documents, publications, and research results (Zainuddin Ali, 2009: 107).

\section{LITERATURE REVIEW}

\section{Definition of the Hajj Fund, Investment and Infrastructure}

\section{Hajj Funds}

Etymologically, according to the Indonesian Dictionary, funds are money provided for a purpose. In terminology, funds are cash and / or other assets that can be immediately cashed and which are available or set aside for certain purposes (Frianto Pandia, 2012: 1).

Hajj literally means al-qasdu which means purpose, purpose and intention. Like the words of someone hajajtu fulānan wa i'tamadt uhu ai qasadt uhu which means I go to him (Ibn Manzur, t.t: 226).

While the pilgrimage according to the terminology of scholars includes:

According to Sheikh Zakaria bin Muhammad al-Anshori in the book Fath alWahhāb bi syarh minhaj al-tulāb, the hajj is:

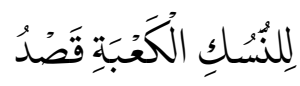

"Towards the Kaaba to carry out certain worship"

According to Abdurrahman al-Jaziri in al-fiqh 'ala al-mazāhib al-arba'ah, the hajj is:

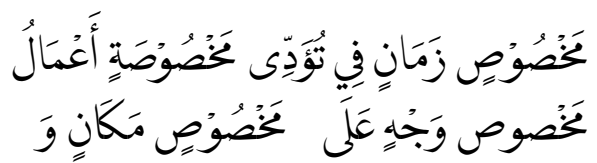

"Certain acts (acts of worship) are carried out at certain times, places and procedures".

Meanwhile, according to Imam Nawawi as quoted by $\mathrm{Abu}$ Bakr bin Muhammad in the book of Kifayah al-Akhyar Hajj is:

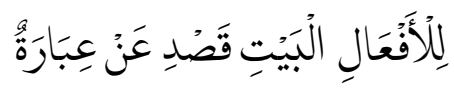

"An expression used to visit Baitullah to carry out acts (of worship)"

From the three definitions above, it can be concluded that Hajj is an expression used for acts of worship carried out in Baitullah (Mecca) at certain times and procedures. 
Simply stated, based on the description above the Hajj fund is a fund prepared to carry out the Hajj. A broader definition which is the subject of the author's study in this thesis is the pilgrimage fund contained in article 2 of Law Number 34 of 2014 concerning Hajj Financial Management, which reads:

"The Hajj Fund is a fund for the cost of organizing the hajj pilgrimage, the efficiency of the hajj pilgrimage, the endowment fund of the ummah, and the value of benefits controlled by the state in the context of organizing the hajj pilgrimage and implementing programs for the benefit of Muslims."

\section{Investment}

Investment comes from Latin, namely investire (use), while in English it is called Investment (Abd. Manan. 2009: 183). According to the Indonesian dictionary investment is investing money or capital in a company or project for profit.

In Longman English Dictionary, the word invest definition as "Using (money) to make more money from something that will increase value". Furthermore, the word investment is defined as an action or act of investing.

Investment in economic theory is related to physical capital stock, whether it is through the construction of houses, the manufact ure of machinery, the construction of factories / offices or additions to the preparation of goods (Mochammad Nadjib et al, 2008: 55).

Nurul Huda and Mustafa Edwin Nasution in their book Investment in Islamic Capital Markets

1. Investment in the field of money investment in the form of company capital or investment fund investment (Arifin, in the dictionary of capital and financial markets, 1999).

2. Investment is defined as the activity of exchanging money to obtain other forms of wealth such as other movable shares which are expected to be able to be bought for a certain period in order to make money (Wirasasmita, in a dictionary on the capital and financial markets, 1999).
3. Investment is defined as a commitment to funds or other resources made at this time, with the aim of obtaining a number of benefits in the fut ure (Tandelilin, 2001)

4. From some of the explanations above it can be concluded that investment is an activity of investing special wealth to get benefits in the fut ure.

\section{Infrastructure}

Etymologically, according to the Indonesian Dictionary, infrastructure means infrastructure.

In English, infrastructure is called infrastructure. According to the Longman English Dictionary, the word infrastructure is classified as "Systems that support the operation of an organization."

In terminology, transition infrastructure in physical systems that provide transportation, irrigation, drainage, buildings and other public facilities needed to meet basic human needs in the social and economic sphere (Grigg, 1988). The infrastructure system is the main supporter of the functions of the social system and the economic system in people's daily lives. Infrastructure systems can be defined as facilities or basic structures, equipment, installations, which are built and are needed for the functioning of social systems and economic systems of the community. (Grigg, 2000).

\section{DISCUSSION}

\section{Akad in Hajj Registration}

In practice, prospective pilgrims who wish to register the hajj are required to open a hajj savings account at the Receiving Bank for the Hajj Implementation Fee (BPS BPIH). After the initial deposit or savings has reached at least 25 million prospective pilgrims can register Hajj in the Ministry of Religion Regency / City by bringing documents from banks and other requirements in accordance with the provisions (See the procedure for registering hajj on the Ministry of Religion's website: https://kemenag.go.id/berita/info_grafis_read/8/tata-cara-dan-perRequirementsregistration- hajj- regular). 
Based on the author's observations at the Receiving Bank for the Hajj Implementation Fee (BPS BPIH) (Observations on BNI Syariah Sub Branch Office Kebon Jeruk West Jakarta on October 26, 2018 and Bank Muamalat Branch Office Kedoya West Jakarta on October 8, 2018), the contract used when opening the Hajj savings account is Wadiah or Mudharabah. Whereas when registering Hajj to the Ministry of Religion, the contract used includes a power of attorney or wakalah. Wakalah literally means al-tafwîd (submission) and al-hifz (maintenance) (Abu Bakr, 2004: 273).

Meanwhile, according to the terminology of the scholars, among others, are as follows:

According to Imam Taqiuddin Abu Bakr ibn Muthammad al-Husaini in the book of kifayah al-akhyar, wakalah is:

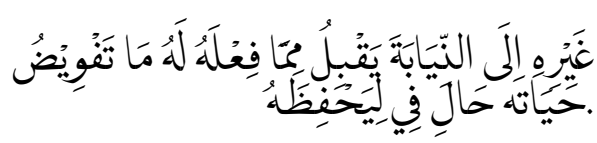

"Giving up a job that can be replaced by someone else to be managed and maintained during his lifetime"

According to Shaykh al-Islam Zakaria bin Muhammad al-Ansori in the book Fath alwahhāb bi syarh minhaj al-tulāb, wakalah is:

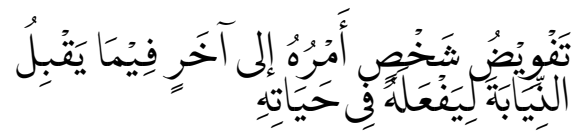

"Submission of one person to another for a job that can be replaced to be done during his lifetime"

From the two definitions above it can be concluded that wakalah is a contract where someone appoints another person to replace him in an affair/work that can be replaced during his lifetime. Ijma ulama allow wakalah because wakalah is seen as a form of help to help on the basis of kindness and piety ordered by Allah Almighty and His Messenger.

\section{Use of Hajj Funds for Infrastructure Investment in a Positive Legal Perspective}

With the ratification of Law Number 34 of 2014, it also provides the mandate for the establishment of the Hajj Financial Management Agency (abbreviated as BPKH).
BPKH has the special task of managing hajj finances, as mentioned in article 22 which reads:

"BPKH is tasked with managing Hajj Finance which includes revenue, development, spending, and accountability for Hajj Finance."

In carrying out these tasks, as Article

24 BPKH has the authority:

a. Placing and investing the Hajj Finance in accordance with the principles of sharia, prudence, security, and the value of benefits; and

b. Cooperating with other institutions in the context of managing Hajj Finance.

c. With regard to the authority to invest Hajj funds, also mentioned in article 46 paragraph 2 of Law No.34 of 2014:

"Hajj finance as referred to in paragraph (1) may be placed and / or invested."

The permitted investment form is mentioned in article 48 paragraph 1 of Law no. 34 of 2014 concerning Financial Management of Hajj, including the following: Hajj Financial Placement and / or investment can be done in the form of banking products, securities, gold, direct investments and other investments.

Further provisions regarding the type of investment permitted are regulated in article 27 , article 28 , article 29 , article 30 , article 31 Government Regulation of the Republic of Indonesia Number 5 of 2018 concerning the Implementation of Law Number 34 of 2014 concerning Hajj Finance:

Article 27 paragraph 1 states that the referred sharia banking products include current accounts, time deposits and savings. Paragraph 2 Mention that during the 3 (three) years since BPKH was formed, the pilgrim financial expenditure in the form of Islamic banking products is at most $50 \%$ of the total pilgrimage financial investments and investments. Whereas paragraph 3 states that after 3 years the BPKH was formed, placements in the form of Islamic banking products were no more than $30 \%$ of the total hajj financial investment placements.

Article 28 paragraph 1 mentions Hajj financial investment in the form of securities including state sharia securities issued by the 
central government, sharia securities issued by Bank Indonesia, and sharia securities regulated and supervised by the Financial Services Authority. Sharia securities which are regulated and monitored by the Financial Services Authority, as mentioned in paragraph 2 include sharia shares listed on the stock exchange, sukuk, sharia mutual funds, sharia asset-backed securities, sharia real estate investment funds, and other sharia securities.

Article 29 paragraph 1 states that the pilgrimage financial investment in gold can be done in the form of certified gold bars produced and / or sold domestically and / or in the form of gold accounts managed by Islamic financial institutions that are regulated and supervised by the Financial Services Authority. Paragraph 2 of the a quo Government Regulation states that the maximum investment limit in this form is a maximum of $5 \%$ of the total hajj investment and/or financial investment.

Article 30 paragraph 1 states that direct investment can be carried out by owning a business, capital participation, investment cooperation, and other direct investments. Paragraph 3 of the a quo Government Regulation states that the maximum investment placement in this form is a maximum of $20 \%$ of the total financial investment placement and/or pilgrimage.

Article 31 paragraph 1 states that other investments that are allowed are determined by BPKH. Paragraph 2 of the a quo Government Regulation states that the maximum limit for investment in this form is $10 \%$ of the total placement and/or financial investment for hajj.

The principles that must be considered in the placement and / or investment of Hajj finance are mentioned in Article 48 paragraph 2 of Act No. 34 of 2014 concerning Financial Management of Hajj, among others as follows:

"Placement and / or investment of Hajj Finance as referred to in paragraph (1) is carried out in accordance with sharia principles by considering aspects of security, caution, value of benefits, and liquidity."
An explanation of these principles, among others, is as follows (See explanation of Article by Article Law Number 34 of 2014 concerning Hajj Financial Management p.3):

"What is meant by the principle of" sharia principles "is all and every management of Hajj Finance based on Islamic principles which are kafah or comprehensive."

"What is meant by the principle of" precautionary principle "is that the management of the Hajj Finance is carried out carefully, thoroughly, safely, and in an orderly manner and by considering aspects of financial risk."

"What is meant by" security aspect "is that the management of Hajj Finance must be carried out by prioritizing the security aspect in anticipating the risk of loss of Hajj Financial management to guarantee the financing of Hajj Implementation. In addition, in investing it also considers aspects of risk including default, reputation, market and operational risks. "

"What is meant by" benefit value "is that a portion of the Hajj Fund can be placed and / or invested on sharia principles and considers risk factors and is liquid."

"What is meant by" liquidity "is to consider the ability and smoothness of payments in the context of the implementation of the current and future pilgrimage services."

Therefore, based on the description above the pilgrimage fund consisting of funds for the cost of organizing the pilgrimage, the efficiency of the pilgrimage, the endowment fund of the people, as well as the value of benefits controlled by the state in the context of organizing the pilgrimage and the implementation of program activities for the benefit of the people can be invested if it is carried out in accordance with sharia principles by considering the aspects of security, caution, value of benefits, and liquidity.

This was also strengthened by the decision of the Constitutional Court Number 51 / PUU-XV / 2017 which was decided in the Consultative Consultative Meeting by seven Constitutional Justices consisting of Anwar Usman, Aswanto, Wahiduddin Adams, Manahan MP Sitopmpul, Saldi Isra, I Dewa Gede Palguna, and Maria Farida Indriwati, on 
Monday, December 4, 2017 and said in the Plenary Session of the Constitutional Court on Tuesday, 12 December 2017 which decided to reject the petition of the petitioner so that Article 24 letter a, Article 46 paragraph (2), and article 48 paragraph (1) of Law 34/2014 (relating to the authority to invest Hajj funds) should be declared contrary to Article 28D paragraph (1) of the Constitution 1945.

\section{Use of Hajj Funds for Infrastructure Investment in the Perspective of Islamic Law}

Regarding the law on the use of Hajj funds for infrastructure investment is included in the shutter of ijtihad (In the language of من فعل في الوسع واستغراغ المجهود بذل ibtihad is "mobilize the ability of a job" or some وسعه الفقيه بذل work", in terms of the term is وسأحس العلم فيطلب "law" to mobilize the ability of a law or some work "the term" law "for the legality". M Khudri Beik, Usul al-Fiqh, (Cairo: Dar al-Hadith, 2003), p.359), where there is no text that explicitly mentions the law. In addition, it also considers the aspects of maslahat and harm that are the main objectives (maqasid al-shari'ah) in Islamic law.

In Indonesia, the institution that brought together Muslim scholars to formulate a fatwa, the largest being the Indonesian Ulama Council.

Based on the results of interviews with Dr.dr. Endy Muhammad Astiwara as a member of the Fatwa Commission as well as a member of the National Sharia Council of the Indonesian Ulama Council, the law on the use of hajj funds for infrastructure has never been stated by the fatwa commission. According to him, this matter had already been discussed but had not been reported because it remembered many aspects that had to be studied and considered starting from the economic aspects to the political aspects of government. According to him, until now the discussion on the legal use of hajj funds for infrastructure has not been rescheduled (Interview with members of the fatwa commission DR.dr. Endy Muhammad Astiwara on May 23, 2018 at the Office of the Indonesian Ulama Council Fatwa Commission).
Although the specific problem of using hajj funds for infrastructure has not been stated yet, the ability to process hajj funds to be productive has already been stated when discussing the ownership status of BPIH deposit funds which are included as a waiting list. In formulating the issue of the fatwa, three questions were asked. First, the owner of the Hajj deposit funds that are waiting list. Second, whether or not BPIH deposit funds that are included in the waiting list are invested. Third, who has the right to manage investments (if allowed) and the results for whom. In the fatwa law stipulations there are four points which have the complete sound as follows (The Results of the Ijtima Ulama Decision IV Indonesia IV Fatwa Commission 2012 concerning the Stat us of BPIH Deposit Funds Owned in the Waiting List in Cipasung Pesantren, West Java):

First, the pilgrimage deposit funds that are accommodated in the account of the Minister of Religion whose registrants are included in the waiting list are sharply owned by the registrant (prospective pilgrimage). Therefore, if the person concerned dies or there are shariah obstacles that prevent the prospective pilgrim from leaving, the pilgrimage deposit must be returned to the prospective pilgrim or his heir.

Second, BPIH deposit funds for prospective pilgrims that are included in the waiting list in the account of the Minister of Religion, may be used for productive matters (providing benefits), including placement in Islamic banking or investing in the form of Sukuk.

Third, the results of utilization/ investment are the property of prospective pilgrims who are included in the waiting list (among others, as an addition to savings funds for prospective pilgrims or reduction in real/ real hajj costs). As a manager, the government (Ministry of Religion) has the right to get reasonable / modest rewards.

Fourth, BPIH funds belonging to prospective pilgrims on the waiting list, may not be used for any purpose except to finance the needs in question.

The basis for the determination of the fatwa of the Indonesian Ulama Council, among others, is as follows: 
a. Al-Quran

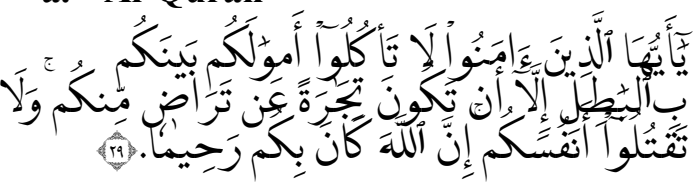

"You who believe, let us not eat your neighbor's goods by way of vanity, except by the way of trade that applies with equal love among you. And do not kill yourself; surely Allah is Most Merciful to you "(QS. Al-Nisa [4]: 29).

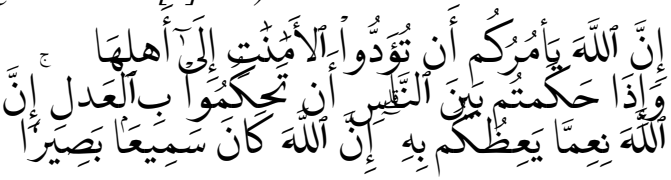

"Verily, Allah tells you to deliver the message to those who are entitled to receive it, and (tells you) if you establish a law between humans so that you determine it fairly. Surely Allah gives you the best teaching. Surely Allah is All-Hearing, All-Seeing. (Surat Al-Nisa '[4]: 58)

\section{b. Hadis Nabi SAW:}

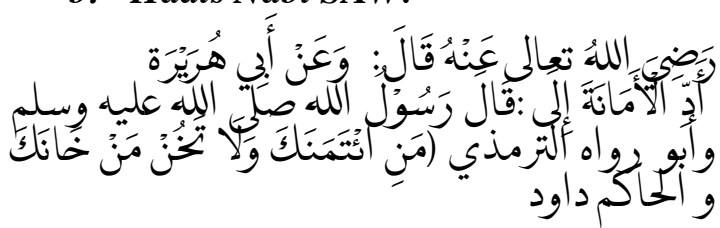

From Abi Hurairah ra. he said: The Messenger of Allah said: "Put on the mandate of those who give to you and do not betray those who betray you". (Narrated by Al-Tirmidhi, Abu Dawud, and alHakim)

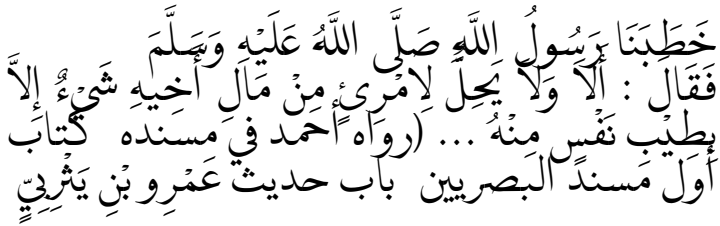

"Rasulullah SAW deliver sermons to us; his saying: 'Know: it is not lawful for anyone in the least of the wealth of his brother except by the willingness of his heart ... "' (H.R. Ahmad).

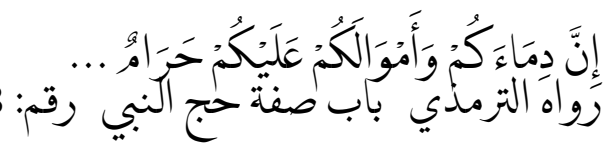

"Indeed your blood (soul) and treasure are haram (noble, protected) ..." (H.R. Tirmizi).

\section{c. Rule of Fiqhiyyah}

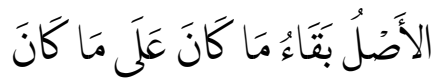

"The Basic Law still applies as before (before the new rules)"

\section{d. Opinion of Accounting and Auditing Organizations for Islamic Financial Institutions (AAO IFI):}

"The lessor may ask the party who promised to lease to pay an advance to the Institution as a guarantee of seriousness in fulfilling his promises and obligations, provided that the funds are only as a substitute for real losses if the tenant fails to promise. These advances may be used as a wadi'ah that cannot be used by the lessor, or can be used as investment capital on condition that the lessee gives permission to the lessor to invest the funds with the Mudharabah contract. Tenants and Tenants can make an agreement that the trust fund is part of the Ujrah installments." (Opinion of Accounting and Auditing Organizations for Islamic Financial Institutions (AAOIFI) (Sharia Standard No. (3) on leasing of persons).

In line with the fatwa of the Indonesian Ulama Council, more specifically the Bahtsul Masail Waqi'iyyah National Deliberation Forum (Munas) Alim Ulama Nahdhatul Ulama in West Nusa Tenggara, is questioned by the law of investing BPIH initial deposit funds in infrastructure projects, whose rights are the investment benefits and who is responsible if there is a loss in investment. The answers to these questions include (The results of the decision bahtsul masail waqi'iyyah national deliberation of Alim Ulama Nahdlatul Ulama in West Nusa Tenggara on November 23-24, 2017):

"Yes, as long as the investment is considered more profitable and safer. While the investment profits belong to prospective pilgrims. If there is a loss, then the government is responsible"

References used in the results of the bahtsul masail include:

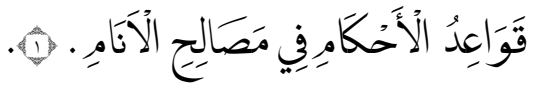

"Trustees and their successors can utilize trustworthy assets (muwalla alayhi) to those who are more beneficial because they attract benefits and reject harm, even not limited to the actions of one of them (trustees) to choose a benefit (sholah) even though they can choose the more beneficial (ashlah), except if the choice can lead to very difficult circumstances (it is not allowed) " (Qawâ'id al Ahkâm Fî̀ Mashâlih al-Anâm) 


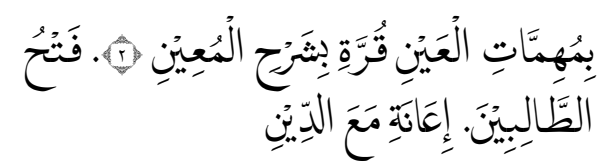

"The trustee must protect the trustworthy assets (muwalla alayhi), the trustee can also utilize the trustworthy property by weighing the benefits, in addition the trustee can grow his wealth if possible a size for a living, zakat, and fees ... Trustees may lend the wealth of those who can afford if forced. And the 'judge' may do the same absolutely with the borrower's record of a rich and trustworthy person". (Fath al-Mu'în bîsyarh Qurrat al-'Ain Bimuhimmât al Dîn Ma'a I'ânat al-Thâlibîn).

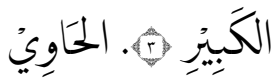

"Imam Shafi'i rahimahullah said:" I like that the trustee of the person as follows trades / develops his property, and the trustee does not bear (if there is a loss). Umar r.a had traded / developed orphans, and Siti Aisyah r.a had traded / developed the wealth of the children of Muhammad bin Abi Bakr in the sea where they were orphans. "Imam Mawardi has said: this as once said, jurists think may orphans trading/developing orphans' property on the conditions that have been considered. " (AlHâwî al-Kabîr)

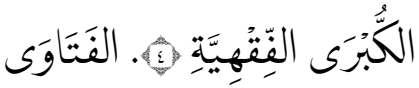

"Sheikh Ibn Hajar al-Haitami was once asked whether the words of Ibn Kabn stating that the trustee must not represent the sale of the person he has to the wicked, is your opinion unmistakeable? Shaykh Ibn Hajar answered: yes, that is an opinion that is not easy because it is to safeguard the benefit of the trustee (muwalla alayhi)." (Al-Fatâwâ alFiqhiyat al-Kubrâ).

$$
\text { الكويتية الفقهية هـه الموسوعة }
$$

"As for the Shafi'ite Schools, they specify on this issue: A trustee cannot lend trustworthy property (muwalla alayhi) except in an emergency, but for a 'judge' may lend it even in a non-emergency situation (this opinion differs from the opinion of Sheikh as -Subki) on condition that the person who borrowed is easy to replace, trustworthy, and there is no doubt about the safety of the trustable property. If there are doubts, bail must be witnessed and taken." (al-Mausû'ah al-Fiqhiyah alKuwaitiyah).

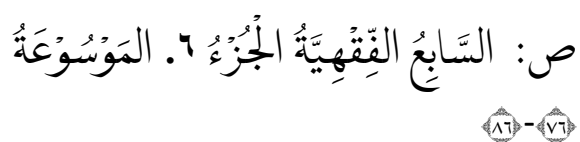

"The law develops the property of others (other than slaves) for those who have the authority to use it: People who have the authority to use the property of others (other than slaves) such as guardians, those who carry out the will, wakaf administrators, representatives, judges, and the government. They can make use of the property of orphans, the weak, waqf, people who are represented, and the Baitulmal with the permission of the Syara. They are the keepers of the treasure. Their view of these assets is an advantage for those who own property. Therefore, developing wealth is a more profitable thing." (Al-Mausû'ah alFiqhiyyah, Juz $7^{\text {th }}$ P. 76-86).

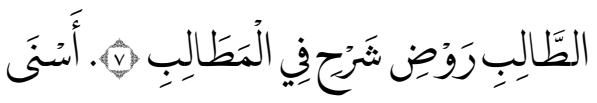

"(A branch of the problem) It is permissible for the 'priest' to distribute the spoils of war without the person who should distribute it to those who are entitled to receive it if the priest sees another benefit. This is because the 'priest' is the guardian of the treasure. Another case of zakat property, may not be given except by people who damage it such as from livestock, fruits and so on. As Shoimuri said." (Asnâ al-Mathâlib Fî Syarh Raudhi alThâlib).

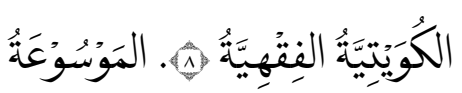

"The famous divide control into two parts: yad amânah, and yad daman. Yad amânah is guarding something or property because it is to replace instead of possessing. " (Al-Mausû'ah al-Fiqhiyyah al-Kuwaitiyah).

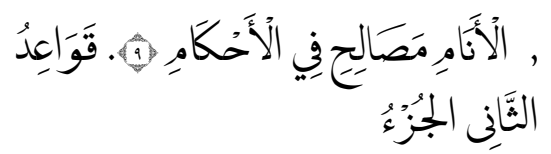

"Whoever intentionally removes / damages something (belonging to another person) for reasons that are not justified, then it is obligatory to replace it due to changing the person's rights. And excluded in this matter are several issues .... Fifth: Imams and Judges if both eliminate / damage the lives or property of others when utilizing it then the obligation to replace it is Baitul Mal, not the Imam, Judge, and people who are intellectual actors according to Imam Shafi'i. Because the utilization of imams and judges for Muslims is like the Muslims themselves who eliminate / destroy it." Qawâ'id al-Ahkâm Fî Mashâlih al-Anâm, Juz 2).

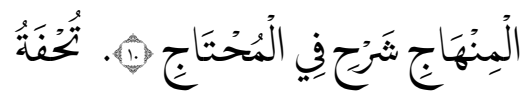

"Like Ibn Solah's fatwa, the Guardian may rent out a garden that is guarded with something that can benefit his garden and produce fruit, then musaqah (Musaqah is a collaboration between the owner of the land / garden and the manager / cultivator to maintain and care for the land / garden with a number of production sharing agreements according to mutual agreement) the tree with 1000 
parts for orphans and the rest for the tenants, and discussion will come about musaqah. Al-Mawardi has said: "Guardians cannot buy something that they fear is damaged, even if it is profitable." (Tuhfat al-Muhtâj Fî Syarh al-Minhâj).

The author agrees that the pilgrimage fund can be invested, because if left unchecked there will be the potential for inflation. However, the authors disagree if the pilgrimage fund is absolutely permitted to invest in infrastructure, with the following reasons:

1. The wakalah contract as the writer described in CHAPTER III was only implemented in 2014 (This is because the basis for the wakalah / power of attorney agreement is Article 6 paragraph (2) of Law No.34 of 2014 concerning Hajj Financial Management). So the pilgrim candidates who registered before 2014 did not sign the wakalah agreement. In other words, before 2014 there was no permit from the prospective pilgrims to fund the government. By being placed in investments, moreover investments outside the interests of the pilgrims are a tyranny (The wrongdoers that are meant here in terms of language, as according to al-Jurjani in his book al-ta'rifât;

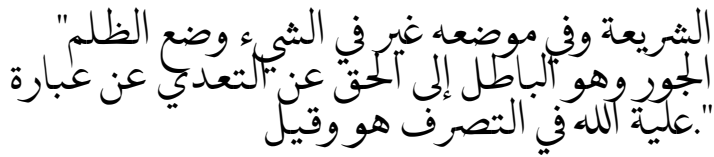

See; Ali ibn Muhammad al-Jurjani, al-ta'rifât, (Beirut: Dar Kutub al-lllmiyyah, 1983), p.144). This is also in accordance with the principles of fiqh which state:

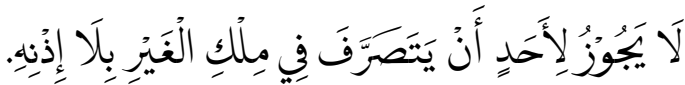

"A person must not use people's property without his permission" (Abd. Aziiz. 2005: 505)

2. Since the beginning of depositing the Hajj Pilgrimage Cost (BPIH) through the Receiving Bank for Hajj Pilgrimage Fee Payment (BPS BPIH) there is no contract clause stating that the hajj money is allocated to certain fields such as government infrastructure. The contract clause offered only states the willingness of prospective pilgrims to open Hajj savings in BPS BPIH funds invested by the Ministry of Religion. By being used outside the interests of the Hajj pilgrims such as in the field of government infrastructure, not all prospective pilgrims will give up their assets. This is not in accordance with the hadith of the Prophet PBUH from Anas bin Malik:

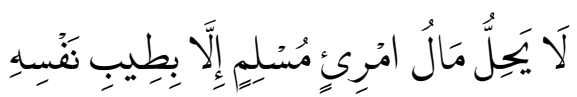

"The property of a person cannot be lawful except by his willingness" (Al-Imam Ali Sunan alDarqutni. 2001: 605)

Another case if used for the benefit of the Hajj congregation can already be known willingness ('ulima ridahu).

3. There is no other choice for prospective pilgrims than to sign a wakalah agreement as a requirement for registering Hajj. If you may choose, it is not certain that all prospective pilgrims will be willing to use the money for investment, let alone investments outside the interests of prospective pilgrims. In other words, there is an element of force even though it is implied. Whereas a contract should be based on voluntary filtering, as the rules of figh:

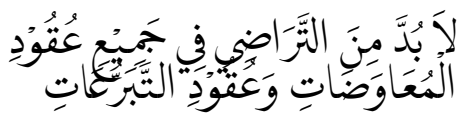

"There Must Be Mutual Rationale in Every Covenant That Is Mu'wadhah (Business) Or Tabarru '(Donations)" (Abdul Muhsin. 2001: 122)

4. Rule of Fiqh Stated :

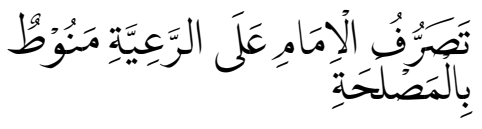

"Tasarruf imam (government) of the people is limited by looking at the benefit" (Abdul Aziz. 2005: 260) 
5. The above rule states that the priest/ government must act in accordance with the benefit of its people. The relation with the pilgrimage fund, the benefit of the owner of the fund, namely the prospective congregation of the heart must certainly take precedence over the benefit of others.

6. Investment risks in the infrastructure sector are considered to be quite large. This is not in accordance with the formulation of bahtsul masail which states that it must be placed in safe investment. Conversely, Hajj funds should be placed in investments that are low risk / low risk even, if any, placed in investments approaching zero risk even though income tends to be small. As the rules of fiqh state:

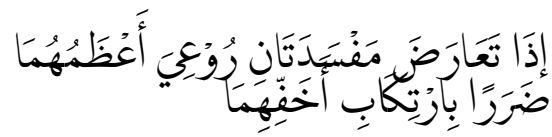

"If two spoilers spoiled, the greatest of them are detrimental to the commission of their". (Syekh Muhammad Shidqi. 1996: 260)

7. Investment opportunities in the field of Hajj are very much like the construction of Hajj Hospitals, Hajj Hotels, Hajj Plane and so on. Placement in the more general sector (such as government infrastructure) is not appropriate unless all investments in the field directly related to the owner of the fund (prospective pilgrims) have been fulfilled.

Therefore, based on the fatwa of the Indonesian Ulama Council, pilgrimage funds can be produced by investing. More specifically, the results of the Bahtsul Masail Ulama Nahdlatul Ulama (NU) state that the hajj funds may be invested in infrastructure provided the investment must be safe. If there is a loss in investment, the government must be responsible. While the authors argue that the pilgrimage fund cannot be absolutely invested in infrastructure but there must be willingness from prospective pilgrims and must prioritize the interests of pilgrims by allocating these investments in sectors directly related to pilgrims.

\section{Legal Comparison of the Use of Hajj Funds for Infrastructure Investment}

The term legal comparison comes from the translation of the words comparative law, comparative jurisprudence, foreign law (English). Droit compare (French), Rechtsgelijking (Dutch), and rechtverleichung, or vergleichende rechlehre (German) (Ishaq. 2012: 134).

According to Ishaq, comparative law is a branch of legal science that compares by finding differences and similarities between legal systems that apply in one or several countries or communities (Ishaq. 2012: 135). Rudolf D. Schlesinger in his book Comparative Law (1959) as quoted by Soedjono Dirdjosisworo in his Introduction to Law, argues that legal comparison, is a method of investigation with the aim of gaining deeper knowledge about certain legal materials (Sordjono Dirdjosisworo.2001: 60).

Comparative law in the perspective of Islamic law, known as muqaranah almadzahib (Comparison of Schools). The word muqaranah comes from Arabic which means to connect something with something else. Or connect something and put it face to face with another. According to the terms, muqaranat means comparison. In simple terms, comparison can be interpreted as an activity to carry out identification of similarities and / or differences between two or more specific symptoms. Thus, muqarah al-mazahib is a scientific activity to identify the similarities and differences between the opinions of two or more scholars in the field of legal thought (madzhab), both in the systematic sources of law, as well as in istinbath law (exploring and establishing law). (Hasanuddin AF et al. 2003: 110).

The comparison discussed in this chapter is used in the sense of comparing the legal use of Hajj funds for infrastructure investment between positive law in force in Indonesia and Islamic law represented by the decision of the fatwa of the Indonesian Ulama Council and the results of the Bahtsul Ulama Nahdhatul Ulama.

Viewed from the point of view of the equation, the authors analyze at least four equations, including the following: 
First, both positive law and Islamic law together provide space for pilgrimage funds that are piled up so that they are developed rather than left alone which can potentially inflation.

Secondly, both positive law and Islamic law require that the management of the development of haj pilgrimage should be based on sharia principles and caution because the money actually developed belongs to Muslims who want to go on the pilgrimage.

Third, both positive law and Islamic law require that the development of hajj funds must meet the benefits or benefits.

Fourthly, the profits derived from the development or investment are the property of the Hajj Candidates (CJH) which will be used for the Hajj.

Viewed from the point of view of differences, there are two differences, including the following:
First, Islamic law absolutely states that if there is a loss, the government must back up. While the positive law as article 53 paragraph 1 of Law No.34 of 2014 concerning Management of Financial Hajj, states that the manager is jointly responsible only if there is a loss on the placement and / or investment of the overall Hajj Finance caused by errors and / or negligence in its management.

Second, the positive law does not directly mention the type of investment that is permitted to use the hajj fund as long as the principles of sharia, security, value of benefits, liquidity and prudence are met. While in Islamic law, the results of Bahtsul Masail Ulama Nahdhatul Ulama specifically mention the type of investment that is permitted, namely in the infrastructure sector.

The following is a legal comparison table for the use of haj funds for infrastructure investment:

\begin{tabular}{|c|c|c|c|c|}
\hline Review & Positive Law & $\begin{array}{l}\text { Islamic Law (Ijtima } \\
\text { Ulama Indonesian Fatwa } \\
\text { Comission iv) }\end{array}$ & $\begin{array}{l}\text { Islamic Law (Bahtsul masail } \\
\text { Ulama Nahdlatul Ulama) }\end{array}$ & $\begin{array}{l}\text { Islamic Law (Author } \\
\text { Analysis) }\end{array}$ \\
\hline Legal Basis & $\begin{array}{lrr}\text { Law No.34 of } & 2014 \\
\text { concerning } & & \text { Hajj } \\
\text { Financial Management }\end{array}$ & $\begin{array}{l}\text { Al-Quran, al-hadith, } \\
\text { principles of } \\
\text { jurisprudence, Opinion of } \\
\text { Accounting and Auditing } \\
\text { Organizations for Islamic } \\
\text { Financial Institutions } \\
\text { (AAO IFI) }\end{array}$ & Al-kutub al-mu’tabarah & $\begin{array}{l}\text { al-Hadits, Rule of } \\
\text { Fiqh }\end{array}$ \\
\hline Investment & $\begin{array}{l}\text { Can be invested, as } \\
\text { long as the investment } \\
\text { in accordance with } \\
\text { sharia principles, } \\
\text { prudence, security, and } \\
\text { value for benefits }\end{array}$ & $\begin{array}{l}\text { Can be translated into } \\
\text { productive things, such as } \\
\text { investing in sukuk }\end{array}$ & $\begin{array}{l}\text { Can be invested, provided it is } \\
\text { profitable and safe }\end{array}$ & $\begin{array}{l}\text { Can be invested, } \\
\text { provided it is } \\
\text { profitable and safe }\end{array}$ \\
\hline $\begin{array}{l}\text { The Benefit of } \\
\text { Investment }\end{array}$ & $\begin{array}{l}\text { Owned by the pilgrism } \\
\text { of hajj }\end{array}$ & $\begin{array}{l}\text { Owned by the pilgrism of } \\
\text { hajj }\end{array}$ & Owned by the pilgrism of hajj & $\begin{array}{l}\text { Owned by the } \\
\text { pilgrism of hajj }\end{array}$ \\
\hline $\begin{array}{l}\text { Investment loss / } \\
\text { risk }\end{array}$ & $\begin{array}{l}\text { A mutual } \\
\text { responsibility of } \\
\text { BPKH if } \\
\text { caused by errors and / } \\
\text { or negligence in its } \\
\text { management. }\end{array}$ & No specific mention & $\begin{array}{l}\text { Absolute } \\
\text { responsibility }\end{array}$ & $\begin{array}{l}\text { Absolute } \\
\text { government } \\
\text { responsibility }\end{array}$ \\
\hline
\end{tabular}

Table 1. Comparison of Legalse of Hajj Funds for Infrastructure Investment 


\section{CLOSING}

In positive law, based on Article 24 letter a, Article 46 paragraph (2), and article 48 paragraph (1) of Law No.34 of 2014 concerning Hajj Financial Management, hajj funds can be invested in infrastructure with conditions that are built according to the principle sharia, value of benefits, and liquidity.

In Islamic law, the MUI fatwa provides the opportunity for haj funds to be invested and the results of the NU's bahtsul masail allow the use of haj funds for infrastructure investment. While the authors argue there must be a willingness from the pilgrimage, if not then it should not be used for infrastructure investment.

\section{ACKNOWLEDGMENT}

First, the authors thank all those who have provided encouragement, guidance, as well as direction so that this research can be done to expand the study of Hajj in the Muslim world. Secondly, the authors thank UIN Syarifhidayatullah for providing moral and material support. Third, the authors express their gratitude to the Editorial Journal of the Al Qalam Journal of the Makassar Institute for Religious Research and Development which is pleased to publish this article, so that it can be read by the wider community.

\section{BIBLIOGRAPHY}

Al-Jaziri, Abdurrahman bin Muhammad Awad., t.th., al-fiqh 'ala al-mazāhib alarba'ah, Kairo : dār ibn al-haitsam, t.t.

AF, Hasanuddin, dkk. 2003. Pengantar Ilmu Hukum. Jakarta: UIN Jakarta Press.

Azzam, Abdul Aziz Muhammad, 2005. Alqawâ'id al-fiqhiyyah, Kairo: Dâr alhadits.

al-Haitami, Ahmad bin Muhammad bin Ali bin Hajar, t,th. al-fatâwa al-fiqhiyyah al-kubra, al-Maktabah al-Islamiyyah.

Ahmad bin Muhammad bin Ali bin Hajr alHaitami, 1983. Tuhfah al-muhtâj fi syarh al-minhâj, Mesir: Maktaba alTijariyyah al-Kubra.
al-Jurjani, Ali bin Muhammad, 1983. alTa'rifât. Beirut: Dar Kutub al'Ilmiyyah.

Ali, Abu al-Hasan bin Muhammad al-Bashri al-Bagdadi (al-Mawardi), 1999. alHâwi al-kabîr fì fiqh mazhab al-imâm al-syafi'I (syarh mukhtasar al-muzani), Beirut: Dar al-kutub al-'ilmiyyah.

Ali, Zainuddin. 2009. Metode Penelitian Hukum. Jakarta: Sinar Grafika.

Bakr, Abu bin Muhammad Al-husaini, 2004. Kifayah Al-Akhyar. Jakarta: Dâr alKutub al-Islamiyah.

Bakr, Sayyid bin Sayyid Muhammad Syata ad-Dimyati. 2009. Hâsyiyah I'ânah altalibîn, Dâr al-Kutub Al-islamiyyah.

Beik, M Khudri. 2003. Ushul al-Fiqh, Kairo: Dar al-Hadits.

Dirdjosisworo, Sordjono. 2001. Pengantar Ilmu Hukum. Jakarta: Rajawali Press.

Fajar, Mukti dan Yulianto Achmad. 2015. Dualisme Penelitian Hukum; Normatif dan Empiris. Yogyakarta: Pustaka Pelajar.

Huda, Nurul dan Mustafa Edwin Nasution. 2007. Investasi pada Pasar Modal Syariah. Jakarta.

Ishaq. 2012. Dasar-Dasar Ilmu Hukum. Jakarta: Sinar Grafika.

Izzu al-Din, Abu Muhammad, bin Abdi alSalam,1999. Qawâid Al-Ahkâm Fî Masâlih Al-Anâm. Beirut: Dar al-Kutub al-Ilmiyah.

Kamus Besar Bahasa Indoneisa Edisi Kelima

Kementrian Wakaf dan Urusan Islam Kuwait. 2006. Al-Mausû'ah Al-Fiqhiyyah AlIslamiyyah Al-Kuwaitiyyah, Kuwait, Dâr al-Salâsil.

Kodoatie, Robert J. 2005. Pengantar Manajemen Infrastruktur. Yogyakarta: Pustaka Pelajar.

Manan, Abdul. 2009. Aspek Hukum dalam Penyelenggaraan Investasi di Pasar Modal Syariah Indonesia. Jakarta: Kencana.

Marzuki, Peter Mahmud. 2014. Penelitian Hukum. Jakarta: Kencana Prenada Media.

Muhammad Azzam, Abdul Aziz. Al-qawâ'id al-fiqhiyyah, Kairo: Dâr al-hadits, 2005. 
Muhammad bin Mukram bin Ali (Ibnu Manzur). t.th. Lisan Al-Arab. Beirut: Dâr sâdir, jilid.2.

Muhsin, Abdul bin Abdullah al-Zamil. 2001. Syarh al-Qawâ'id al-Sa'diyyah. Riyad: Dâr Atlas.

Nadjib, Mochammad, dkk. 2008. Investasi Syari'ah; Implementasi Konsep pada Kenyataan Empirik. Yogyakarta.

Procter, Paul, dkk. 1982. Longman Dictionary of Contemporary English, Great Britain: Pitman Press.

Shidqi, Muhammad bin Ahmad. 1996. AlWajîz Fî Îdâh Qawâ'id Al-Fiqh AlKuliyyat, Beirut: Muassasah al-Risâlah.

Syaikh Zakaria bin Muhammad, Al-anshori. 2009. Fath Al-Wahhāb Bi Syarh Minhaj Al-Tulāb. Kairo: Maktabah al-syurūq al-dauliyyah.

Utsman, Abu Bakar bin Muhammad Syata alDimyâti. 2009. I'ânah al-tâlibîn 'ala halli al-fâz fath al-mu'în. Jakarta: Dar kutub al-Islamiyyah.

Zakaria bin Muhammad al-Ansori, t.th. Asna Al-Matâlib Fî Syarh Raud Al-Tâlib. Dâr al-Kutub al-Islâmi.

\section{NEWSPAPER}

Dana Haji Dikhawatirkan untuk Tambal Utang Pembangunan Infrastruktur, http://nasional.kompas.com/read/2017/ 08/06/17575371/dana-hajidikhawatirkan-unt uk-tambal-utangpembangunan-infrastruktur.html, Diakses pada 6 Agustus 2017.

Maruf Amin: Saya yang Tanda Tangani Fatwa MUI Soal Dana Haji untuk Pembangunan Infrastruktur, http://wartakota.tribunnews.com/2017/ 08/01/maruf-amin-saya-yang-tandatangani-fatwa-mui-soal-dana-hajiuntuk-pembangunan-infrastruktur, Diakses pada 22 September 2018
Pro kontra dana haji untuk pembiayaan infrastruktur,

https://beritagar.id/artikel/berita/prokontra-dana-haji-untuk-pembiayaaninfrastruktur, diakses pada 28 Maret 2018

Tata Cara dan Persyaratan Pendaftaran Haji Reguler, https://kemenag.go.id/berita/info_grafi s_read/8/tata-cara-dan-persyarat anpendaftaran-haji-reguler, diakses pada 7 Mei 2018.

\section{LEGAL}

Undang-Undang No.34 Tahun 2014 tentang Pengelolaan Keuangan Haji

Peraturan Pemerintah Republik Indonesia Nomor 5 Tahun 2018 Tentang Pelaksanaan Undang-Undang Nomor 34 Tahun 2014 Tentang Keuangan Haji.

\section{DECISIONS AND FATWA}

Hasil Keputusan Ijtima Ulama Komisi Fatwa Se-Indonesia IV Tahun 2012 tentang Status Kepemilikan Dana Setoran BPIH Yang Masuk Daftar Tunggu (Waiting List) di Pesantren Cipasung Jawa Barat.

Hasil keputusan bahtsul masail waqi'iyyah musyawarah nasional alim ulama Nahdlatul Ulama di Nusa Tenggara Barat pada tanggal23-24 November 2017.

Hasil Keputusan Bahtsul Masail Forum Musyawarah Pondok Pesantren (FMPP) se-Jawa Madura ke-31 di Pondok Pesantren Salaf Sulaiman Trenggalek Jawa Timur 18-19 Oktober 2017 M/ 2829 Muharram $1439 \mathrm{H}$.

Putusan Mahkamah Konstitusi Nomor 51/PUU-XV/2017. 